\title{
A REVISION OF THE AMERICAN SPECIES OF THE GENUS OZYPTILA
}

\author{
By Elizabeth B. BRyant \\ Museum of Comparative Zoölogy, Cambridge, Mass.
}

The genus Ozyptila was made by Simon in 1864 for the single species Thomisus claveatus Walckenaer (Ins. Apt.; 1837, 1, p. 510, Aug., 1833, Pyrenees), and wrongly identified as Thomisus hirtus Savigny, 1837, from Egypt. O. claveata of Walckenaer has not been recognized and in 1875 (Arach. France, 2, p. 211), Simon renamed the species that has been called claveata by Blackwell and others O. blackwalli, and selected Thomisus brevipedes Hahn as type of the genus.

The genus has a wide distribution in Europe with many species. In America all the species were known first from females, wth the exception of $O$. marshalli Barrows. Recently in revising the material at the Museum of Comparative Zoölogy the males have been identified and two new species were found. The males are easily distinguished by the palpi and the females by the epigynes. The clavate bristles may have specific value, but they are easily broken and the scar is difficult to see, so that they are found to be unsatisfactory. The number and position of the spines on the anterior legs is apparently constant throughout the genus, with the possible exception of $O$. nevadensis Keyserling, which is known only from the description. This is supposed to have two lateral spines on the first metatarsi instead of one. The color markings are also disappointing.

The genus is not well represented in collections, as the spiders are small, of a dull brown color with indistinct marks and as they live on the ground they are easily overlooked. Nine species have been recognized, known by both sexes, with the exception of $O$. neglecta and $O$. marshalli, which are represented only by the males. O. mar- 
shalli is the only species not in the Museum of Comparative Zoölogy collection, and that is known only by the type.

I am greatly indebted to Mr. Banks for his unfailing kindness and help, and to Mr. J. H. Emerton for the generous use of his collection. Dr. W. M. Barrows has very kindly allowed me to examine the type of $O$. marshalli, and has generously given to the Museum of Comparative Zoölogy O. neglecta collected by him at Hayden Falls, Columbus, Ohio.

\section{Ozyptila}

Cephalothorax slightly elevated. Anterior and posterior rows of eyes procurved, posterior row longer, laterals larger than medians and on separate tubercles, the anterior being the larger. Quadrangle higher than wide, usually with parallel sides, but occasionally wider in front. Abdomen depressed, broad at base and rounded behind. Legs short and stout, I and II longest, tibia with 2-2 spines, metatarsus, 2-2-2 spines beneath and one or more lateral. Cephalothorox and abdomen roughened, and with the legs usually covered with clavate bristles and spatulate hairs. Male palpus rather short, tibia but little longer than patella, with two or three apophyses. Palpal organ simple. But little difference in size and markings between the sexes.

\section{Ozyptila}

\section{Males}

1. Tibia of male palpus with two apophyses, one superior and one inferior ......................................... 2

Tibia of male palpus with three separate apophyses, one superior, one inferior and a small one intermediate

2. Superior apophysis forked, upper branch bent almost. parallel to tibia marshalli Superior apophysis not forked 3

3. Superior apophysis slender and more than half the length of the tarsus; inferior apophysis thickened 
bent downward, embolus long and tip bent at right angles conspurcata

Superior apophysis less than half the length of the tarsus

4. A crescent-shaped piece in lower part of palpus... 5

No crescent-shaped piece in palpus …................ 6

5. Superior apophysis of tibia, short and very heavy, crescent-shaped piece with serrate edge ............... modesta

Superior apophysis slender, reaching almost to middle of tarsus

americana

6. Inferior apophysis slender and straight, embolus following curve of palpal cavity monroensis

Inferior apophysis thin and folded, lower apophysis of palpus bifid neglecta sp. $\mathrm{n}$.

7. Superior apophysis more than half the length of tarsus, slender, with a small tooth on upper margin near base; inferior apophysis more than half as long as superior formosa sp. n.

Superior apophysis less than half as long as tarsus 8

8. Superior apophysis slender and sinuous, inferior apophysis short, scarcely reaching the palpus, embolus short and ending in a curve. pacifica

Superior apophysis stout and curved, inferior apophysis as long as superior and intermediate leaflike and folded almost double floridana

\section{Ozyptila americana Banks}

Figs. 1, 15

Psyche, 1895, 7, p. 242; ㅇ N. Y.; Ithaca

Oxyptila conspurcata Emerton.

Trans. Conn. acad.; 1894, 9, pl. 4, fig. 7c.

ô $3 \mathrm{~mm}$. long.

Cephalothorax brown with a broad, irregular dark stripe each side of the median light stripe; yellow between median eyes; irregular marginal dark stripe; abdomen 
brown with dark spots and blotches and irregular cream color spots at base; legs brown, femora blotched with darker brown, tibiæ, metatarsi and tarsi light; spines, one spine above on femora I, II and III; I tibia 2-2, metatarsus 2-2-2, 1 lateral, all paired spines longer than diameter of joint. No clavate bristles on edge of clypeus, a pair of small clavate bristles between median eyes. Quadrangle slightly wider in front than behind.

Palpus. Tibia no longer than patella. Superior apophysis of tibia, slender and reaching to the middle of the tarsus; inferior apophysis slender, curving and ending in an enlarged hook bent away from the palpus. Palpal organ rather simple, superior apophysis with widely separated tips and a rounded lobe between, opposite is a sharp black cusp; on the lower opposite side is a dark piece curved to the contour of the palpus. This corresponds to the crescent-shaped piece in $O$. modesta. The embolus ends in a flattened tip which rests on the superior apophysis.

\& $4 \mathrm{~mm}$. long.

Cephalothorax brown with dark stripe each side of median light stripe and an irregular dark margin, cream color between the eye rows; abdomen brown with dark spots and a few cream color stripes; sternum and coxæ light brown, venter mottled; legs, brown, I femur mottled; spines, one spine above on femora I, II and III; I tibia 2-2, metatarsus 2-2-2, 1 lateral; all paired spines longer than diameter of joint, clavate bristles on clypeus longer than distance between A. M. E., pair of clavate bristles between M. E. and a clavate bristle below P. L. E. Quadrangle of eyes a little wider in front than behind.

Epigynum. A broad U-shaped depression with two small dark dots behind and the usual median lobe at the anterior part, much smaller than in $O$. conspurcata.

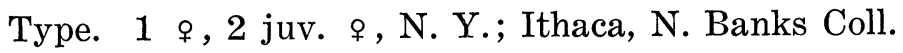

1 \%, Can.; Ottawa bog, 1883, J. H. Emerton Coll., fig. as $O$. conspurcata, Trans. Com. acad.; 1894,9 , pl. 4 , f. 7 c. 1 \&, N. H.; Intervale, Aug., 1910, E. B. Bryant Coll.; 1 , 1 \&, North Woodstock, 4 June, 1908, J. H. Emerton coll., 1 \&, Jackson, 20 Feb., 1906, J. H. Emerton coll. 


\section{Ozyptila conspurcata Thorell}

Fig. 2, 16.

Bull. U. S. Geol. Surv.; 1877, 3, p. 496 ; ९ , Colo.; Manitou Spring, 13 July.

Oxyptila georgiana Keyserling, Spinnen Amer.; Laterigradæ, 1880, p. 52, pl. 1, f. 26. "Many \& Peoria, Georgia, Simon Coll."

Oxyptila conspurcata Emerton, Trans, Conn. acad.; 1894, 9, p. 417, pl. 4, fig. 7 (nec 7c).

ô $3 \mathrm{~mm}$. long.

Cephalothorax brown with distinct light median stripe, sides mottled, with dark spot each side of median stripe; abdomen yellow with scattered cream colored dots and streaks and two pairs of laterally elongated dark spots near the center; sternum and coxæ light, venter light, spotted with dark; legs, I and II darker than III and IV. I femur mottled, the other joints clear, bright brown; spines, one spine above on femora I, 11 and III; I tibia 2-2, metatarsus 2-2-2, as long or longer than diameter of joint, no lateral. No clavate bristles on clypeus. Quadrangle as wide behind as in front.

Palpus. Superior apophysis very long and slender, parallel to tarsus and more than half as long; inferior apophysis short and bent. Palpal organ simple, a small dark cusp near the center near the large dark body; embolus long, slender, curving and resting on this central piece.

o $4 \mathrm{~mm}$.

Cephalothorax brown, markings not as distinct as in male, abdomen darker and marks less distinct; sternum and coxæ light; legs marked same as in male, but the paired spines longer. Clavate bristles on edge of clypeus not as long as distance between A. M. E. Quadrangle as wide behind as in front.

Epigynum. The median anterior lobe is large and has a clear center with a small central spot; beneath are dark converging edges. 
1 \& Can.; Laggan, J. .H. Emerton Coll.; 1 \& N. H.; Intervale, Aug., 1919, E. B. Bryant Coll.; 1 o , 1 \& Mass.; Holliston, 10 June, 1924, Emerton and Banks coll.; 3 ㅇ N. Y.; Ithaca, N. Banks Coll.; 1 \& Cold Spring Harbor, 25 June, 1903; J. H. Emerton coll.; 1 ô Ill.; Riverside, 8 June, 1912, N. Banks Coll.; 1 \& Iowa; Ames, N. Banks Coll.

\section{Ozyptila floridana Banks}

Figs. 3, 4, 18.

Psyche, 1895, 7, p. 243. "1 \& Fla.; Punta Gorda."

of $2.5 \mathrm{~mm}$. long.

Cephalothorax brown, mottled with darker brown to form four irregular stripes; abdomen brown with irregular dark marks in bands, cream color blotches on basal margin; legs, basal part of femora, metatarsi and tarsi light, patella and tibiæ shaded with dark. Spines, one spine above on femora, I, II and III. I tibia 2-2, metatarsus 2-2-2, 1 lateral, the paired spines on metatarsus longer than diameter of joint. No clavate bristles on edge of clypeus, but pair of short clavate bristles between median eyes, and a long clavate bristle over coxæ I. Quadrangle wider in front than behind.

Palpus. Superior apophysis short and bent at an angle, inferior apophysis slender and straight and about the length of the superior and extending a short distance on palpus; intermediate apophysis a thin plate folded almost double. Palpal organ very simple, without apophyses and embolus ending in a curve following contour of palpus.

o $4 \mathrm{~mm}$. long.

Cephalothorax brown mottled with a darker brown, yellow between the eyes; abdomen dark with few irregular markings; legs, tarsi light, and all other joints mottled with dark brown; sternum, coxæ and venter mottled. Spines, one spine above on femora, I tibia 2-2, metatarsus 2-2-2, 1 lateral, all paired spines as long or longer than the diameter of the joint. Clavate bristles on edge of clypeus as long as distance between A. M. E., a pair of clavate bristles between median eyes, and one long clavate 
bristle on margin above coxæ I. Many small clavate bristles on cephalothorax and abdomen, spatulate hairs on legs arranged in rows. Quadrangle wider in front than behind.

Epigynum. A shallow depression divided by a septum, on each side large oblique opening. The usual anterior lobe is large and quite remote from the other parts.

1 \& Type. Fla.; Punta Gorda, Mrs. A. T. Slosson coll.; 1 \&, 2 ô, Dunedin, 1927, W. S. Blatchley coll.

\section{Ozyptila formosa sp. n.}

Figs. 5, 7, 17.

o $3 \mathrm{~mm}$. long.

Cephalothorax dark brown, median light stripe very obscure at anterior portion; abdominal markings indistinct; legs, I femur, patella and tibia dark brown, slightly mottled with light brown; II, III, IV femora light yellow at base, patellæ and tibiæ dark brown; all tarsi and metatarsi light yellow; sternum, coxæ and venter light without markings. Spines; one spine on upper side of all femora; I tibia 2-2, metatarsus 2-2-2, no lateral ; II tibia 2-2, metatarsus 2-2-2, 1 lateral; all paired spines longer than diameter of joint. Quadrangle of eyes slightly narrowed posteriorly. Clavate bristles small and only ordinary bristles on clypeus.

Palpus. Superior apophysis of tibia, with a slight tooth near base on the exterior side, prolonged into a sinuate spine more than half the length of the tarsus, and parallel with it. Inferior apophysis about half the length of the superior, slender and ending in slightly enlarged tip, which rests against a blackened lobe on the lower side of the palpus. The superior and inferior apophyses are separated by a white intermediate lobe. The palpal organ is very simple and has, like the typical Xysticus, a superior and inferior apophysis widely separated; between the two is a small black cusp. At the opposite side is a dark crescentshaped piece. The embolus is short and rests against the superior apophysis. There is a slight tutaculum similar to Xysticus. 
o $4 \mathrm{~mm}$. long.

Cephalothorax dark brown with median light stripe extending to clypeus; sides mottled; abdomen brown with irregular markings in a light cream color and a darker brown; legs not as dark as in the male, the femora more spotted and the contrast not as great between the tarsi and tibiæ. Spines, the same as in the male, except I metatarsi has 1 lateral. Clavate bristles on clypeus as long as distance between A. M. E. Cephalothorax, abdomen and legs covered with white, spatulate hairs. Quadrangle of eyes a little wider in front than behind.

Epigynum. Two oval depressions separated by a septum. At the anterior end is the usual opening with a small hoodlike projecton.

Type. 1 ô, Fla.; Royal Palm Park, 24 March, 1925, W. S. Blatchley coll.

Co-types. 3 \% \& Fla.; Royal Palm Park, March and April, W. S. Blatchley coll.

This species is nearer Ozyptila brevipes Hahn, than any American species. It differs from the other American species in the greater length of the upper apophysis of the male tibia and the characteristic vulva.

\section{Ozyptila marshalli Barrows}

Figs. 8, 10.

Ohio journ. sci.; 1919, 19, p. 357, pl. 15, f. 2, "1 ô Ohio, Sugar Grove, 11 Sept., 1917."

o $3 \mathrm{~mm}$. long.

Cephalothorax dark golden brown, with four darker stripes, lateral broader, the median with a darker line in the center which reaches the thoracic groove; abdomen light with dark marks arranged as parallel stripes on sides but obscure in the center; legs light golden brown, much lighter than the cephalothorax, with faint dark blotches on the first femur, patella and tibia; posterior legs much lighter and markings more obscure. Metatarsi and tarsi of all legs light yellow. Spines, one spine on upper side of all femora; I femur, 3 basal spines, tibia 2-2, metatarsus 2-2-2, 1 lateral. Clavate bristles on clypeus half as 
long as distance between A. M. E. A long, clavate bristle on margin of cephalothorax above palpus. Eyes; quadrangle wider in front than behind.

Palpus. Tibia no longer than patella; superior apophysis of the tibia bent and almost parallel to the upper edge of tibia; from the basal part a smaller spur bent downward. Inferior apophysis slender with an enlarged tip. Palpal organ simple, without apophyses; embolus ending with a bifid tip about the middle; under this are two slender, dark rods close to the largest part of the organ.

Known by the type only.

Type 1 o. Ohio; Sugar Grove, 11 Sept., 1917, W. M. Barrows coll. Ohio State Univ.

\section{Ozyptila modesta Scheffer}

Figs. 6, 20.

Xysticus modesta Scheffer, Ent. news, Phila.; 1904, 15, p. 257, pl. 17, f. 1. "Several females ... Manhattan (Kans.), in June."

Ozyptila beaufortensis Strand, Arch. Naturges, Berlin, 1916, 81, A. 9, p. 124. "2 ô $\hat{o}$ von Beaufort, N. California."

ô $3.8 \mathrm{~mm}$. long.

Cephalothorax brown, mottled behind the eyes, median light stripe as wide as P. L. E. to about half the width at posterior margin; sides mottled with darker brown and a distinct dark marginal stripe; a pair of light spots at posterior part; abdomen pale yellow with darker marks, muscle spots not conspicuous; sternum with dark marks above margin, coxæ light; legs, I femur light, more than half covered with dark brown marks; tibia, metatarsus and tarsus clear yellow; basal part of femora II, III and IV clear yellow with dark rings at apex of femora, middle and apex of tibiæ; tarsi and metatarsi light. Venter mottled. Spines, I femur 2 above, one spine above on femora II, III and IV. I tibia 2-2, about diameter of joint, metatarsus 2-2-2, longer than diameter of joint, no lateral. 
A pair of small clavate bristles between median eyes, and no clavate bristles on margin of clypeus. Quadrangle of eyes as wide in front as behind.

Palpus. The superior apophysis of the tibia is short and stout; the inferior apophysis is short with an enlarged tip, and extends only a short distance on the palpal organ. The palpal organ is simple. The superior apophysis is distinctly lobed, with a small dark cusp between the two lobes. In the opposite side is a large crescent-shaped body with a distinct serrate edge. This corresponds to a smaller one found in $O$. americana and a much heavier piece in $O$. formosa. The embolus is short and curved, with a flattened tip which rests on the upper apophysis.

\& $5 \mathrm{~mm}$. long.

Cephalothorax brown, with two dark stripes each side of median light stripe; light band between eye rows; sternum, coxæ and venter light and mottled with darker brown; legs, I and II mottled and much darker than III and IV. Spines, one spine above on femora I, II and III; I tibia 2-2, not as long as diameter of joint, metatarsus 2-2-2, 1 lateral, paired spines longer than diameter of joint. Clavate bristles on edge of clypeus not as long as distance between A. M. E., a pair of clavate bristles between M. E. and a long clavate bristle on margin above coxæ I. Head rather broad. Quadrangle of eyes as wide behind as in front.

Epigynum. Wider than long; a central septum extends forward in a sharp point; behind are the two small dark spots, more widely separated than in O. americana, and in front the usual median lobe.

Co-type 1 \& Kans.; Manhattan, 10 June, Scheffer coll.; N. Banks coll.; 1 ô Va.; Falls Church, N. Banks coll.; 1 of , 1 o, Ind.; Pine, N. Banks coll.

The male described by Strand as Ozyptila beaufortensis, from Beaufort, N. California (sic) is undoubtedly this species. 


\section{Ozyptila monroensis Keyserling}

Figs. 9, 19.

Verh. zool. bot. Ges. Wein; 1883, 33, p. 671, pl. 21, f. 19. “q Va.; Fortress Monroe, Marx Coll."

ô $1.8 \mathrm{~mm}$. long.

Cephalothorax dark brown, median stripe very faint, light mark at the end of the thoracic groove; abdomen with irregular dark markings; legs clear brown without markings. Spines; I femur, 1 spine on upper side, tibia 2-2, a little longer than diameter of joint, metatarsus 2-2-2, longer than diameter of joint, no lateral; no spines on anterior surface of femora II, III, IV. Quadrangle as wide in front as behind. Clavate bristles on clypeus short.

Palpus. Tibia very broad, especially above the middle, superior apophysis short slender spur, inferior apophysis short with a slightly enlarged tip. Palpal organ simple, with two slender apophyses about the middle and the embolus following the curve of the cavity.

o $3 \mathrm{~mm}$. long.

Cephalothorax bright brown with median stripe a little lighter; light mark at. end of thoracic groove; abdomen coffee color with paired dark blotches; venter brown with scattered light spots; legs clear brown, little lighter than the cephalothorax without markings, but distinct light rings at the ends of patellæ and tibiæ. Spines; I femur, 1 spine on upper surface, tibia 2-2, metatarsus 2-2-2, 1 lateral on basal third; paired spines at least twice the diameter of the joint; no spines on anterior surface of femora II, III and IV. Clavate bristles on clypeus longer than distance between A. M. E. Quadrangle as wide in front as behind.

Epigynum. The small paired openings more than twice their diameter apart. The median hood-shaped body or lobe, rather large and connected with the paired cavities below.

Found from Long Island, New York, south to Virginia, and west to Ohio and Illinois. 


\section{Ozyptila neglecta sp. $\mathrm{n}$.}

Figs. 11, 14.

ô $2.8 \mathrm{~mm}$. long.

Cephalothorax brown, median light stripe very faint, sides mottled, darker about margin; abdomen with irregular dark marks arranged about the five muscle spots; narrow cream color line around anterior margin; legs light brown without markings, femora darker than other joints. Sternum light with dark marks opposite coxæ; coxæ light, venter pale with transverse dark lines. Spines; I femur, 1 on upper side, tibia 2-2, metatarsus 2-2-2, no lateral; no spines on II, III and IV femora. Clavate bristles on clypeus shorter than space between A. M. E. Quadrangle of eyes as wide in front as behind.

Palpus. Tibia very broad, especially before the middle. Superior apophysis short and pointed; inferior apophysis thin and folded. Palpal organ simple, with a bifid apophysis half surrounding a dark circle about in the center. Embolus ending with a short curve near the top of the palpus.

Type. $1 \hat{\text { o }}$, Ohio; Columbus, Hayden Falls, 13 June, 1926, W. M. Barrows coll.

\section{Ozyptila pacifica Banks}

Figs. 12, 13, 21.

Psyche, 1895, 7, p. 243, “1 $q, 1$ ô, Juv. Wash.; Olympia, T. Kincaid coll."

ô $3 \mathrm{~mm}$. long.

Cephalothorax brown, median stripe mottled behind eyes but not a clear yellow in posterior half; sides with two pairs of interrupted darker stripes; abdomen pale, with white, broken lines and dots at base, and a pair of widely separated dark spots about the middle; apex much darker than basal portion; sternum, coxæ and venter light; legs light brown, I and II femora mottled with a darker brown, other joints clear yellow; broken dark bands at tip of III and IV femura and base of tibiæ III and IV. Spines; one 
spine above on all femora, I tibia 2-2, metatarsus 2-2-2, no lateral; all spines longer than diameter of joint. Clavate bristles between median eyes and on edge of clypeus as long as distance between A. M. E. Quadrangle of eyes as wide in front as behind.

Palpus. Superior apophysis short and sinuous, inferior apophysis short and bent downward, between the two a rounded white lobe. Palpal organ with two apophyses bent downward on the outer side and a dark cusp on the opposite, lower side; embolus ending in a thickened tip near the upper part of the palpus.

ㅇ $4 \mathrm{~mm}$. long.

Cephalothorax bright brown, median stripe mottled about eye region, but a clear yellow in posterior half; sides faintly mottled; abdomen pale with cream color lines and spots about basal portion and posteriorly two or three interrupted darker bands; sternum and coxæ pale; legs a little lighter than cephalothorax, I and II without marks, III and IV with broken dark bands at top of femora and patellæ and at base of tibia IV. Spines, one spine above on femora I, II and III; I tibia 2-2, as long as diameter of joint, metatarsus 2-2-2, 1 lateral; the paired spines longer than diameter of joint. Clavate bristles on edge of clypeus equal to distance between A. M. E. Quadrangle as wide in front as behind.

Epigynum. Median lobe close to dark bodies, under the skin and paired openings a diameter apart.

Type. 1 , Wash.; Olympia, T. Kincaid coll.; N. Banks coll. 1 o , Col.; Florissant, N. Banks coll. 1 \& B. C.; Metlakatla, J. H. Keen coll., N. Banks coll. 1 ô, 1 , B. C.; Masset, J. H. Keen coll., N. Banks coll. 


\section{Explanation of Plates}

\section{Plate 18.}

Fig. 1. O. americana Banks, ventral view of palpus.

Fig. 2. O. conspurcata Thorell, ventral view of palpus.

Fig. 4. O. floridana Banks, ventral view of palpus.

Fig. 4. O. floridana Banks, lateral view of palpus.

Fig. 5. O. formosa sp. n., lateral view of palpus.

Fig. 6. O. modesta Keys., ventral view of palpus.

Fig. 7. O. formosa sp. n., ventral view of palpus.

\section{Plate 19.}

Fig. 8. O. marshalli Barrows, ventral view of palpus.

Fig. 9. O. monroensis Keys., ventral view of palpus.

Fig. 10. O. marshalli Barrows, lateral view of palpus.

Fig. 11. O. neglecta sp. n., lateral view of palpus.

Fig. 12. O. pacifica Banks, lateral view of palpus.

Fig. 13. O. pacifica Banks, ventral view of palpus.

Fig. 14. O. neglecta sp. n., ventral view of palpus.

\section{Plate 20.}

Fig. 15. O. americana Banks, epigynum.

Fig. 16. O. conspurcata Thorell, epigynum.

Fig. 17. O. formosa sp. n., epigynum.

Fig. 18. O. floridana Banks, epigynum.

Fig. 19. O. monroensis Keys., epigynum.

Fig. 20. O. modesta Keys., epigynum.

Fig. 21. O. pacifica Banks, epigynum. 
Psyche, 1930

Vol. 37; Plate 18.

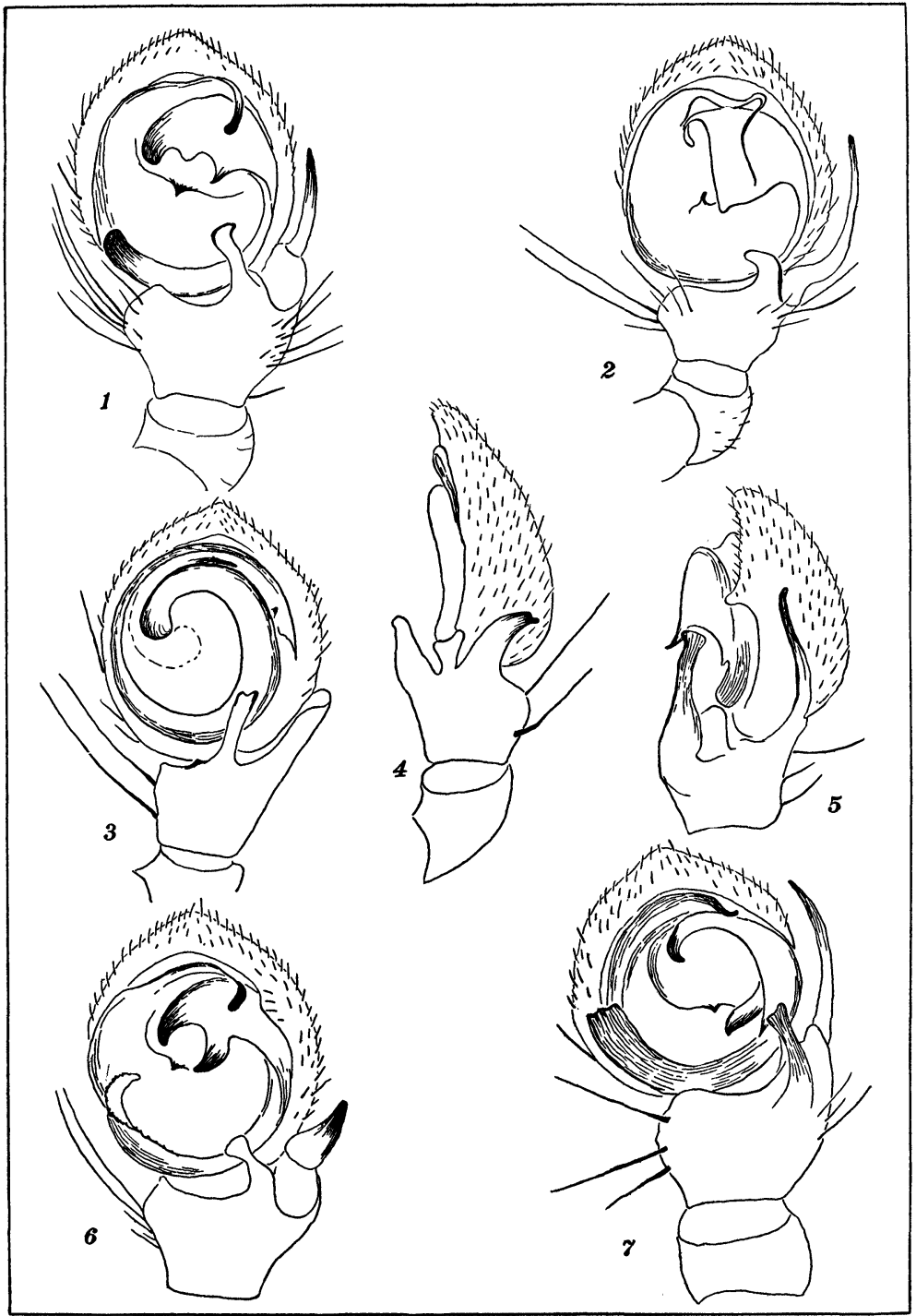

Bryant-American Ozýptila. 
Psyche, 1930

Vol. 37, Plate 19.

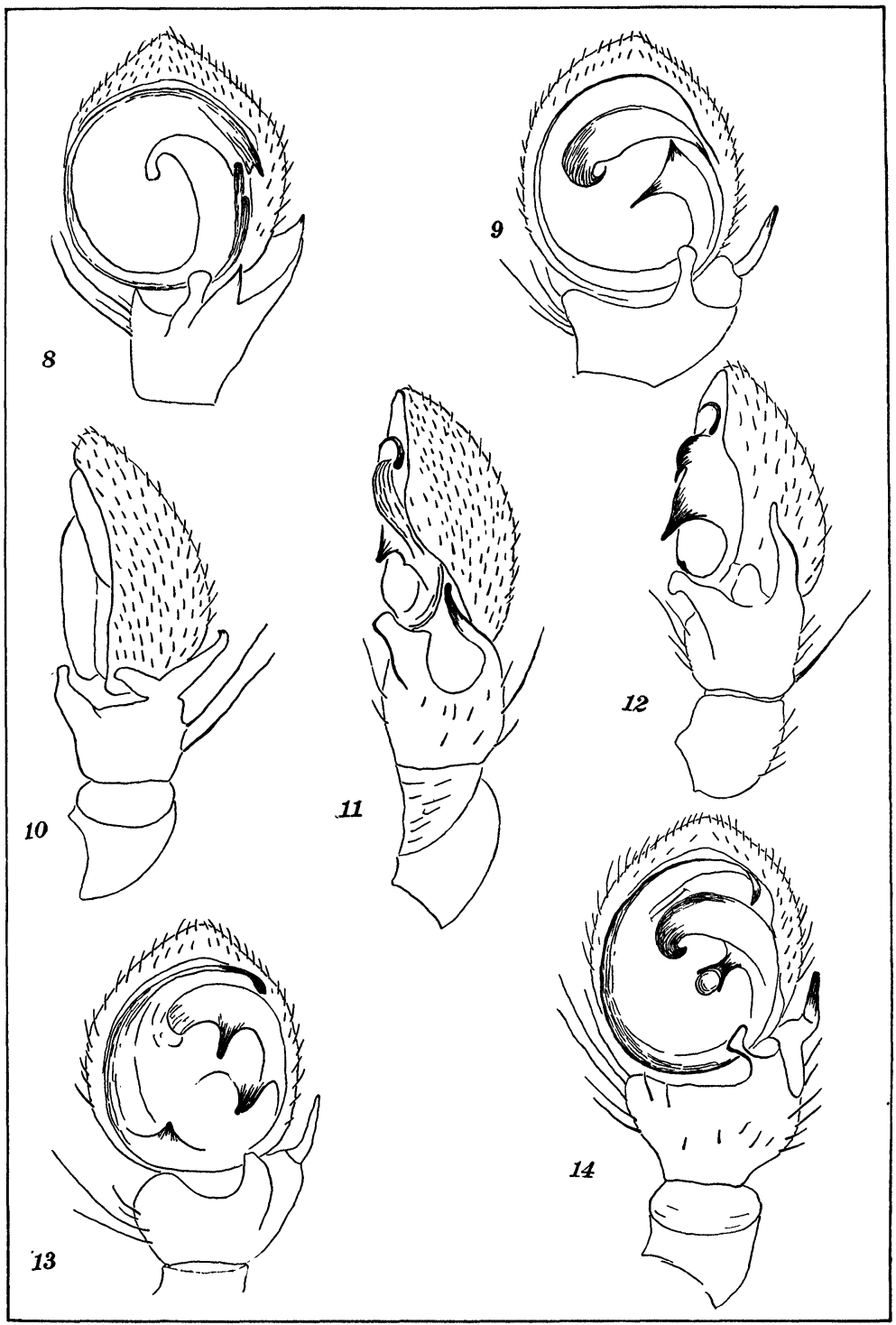

Bryant-American Ozyptila. 
Psyche, 1930

Vol. 37, Plate 20.

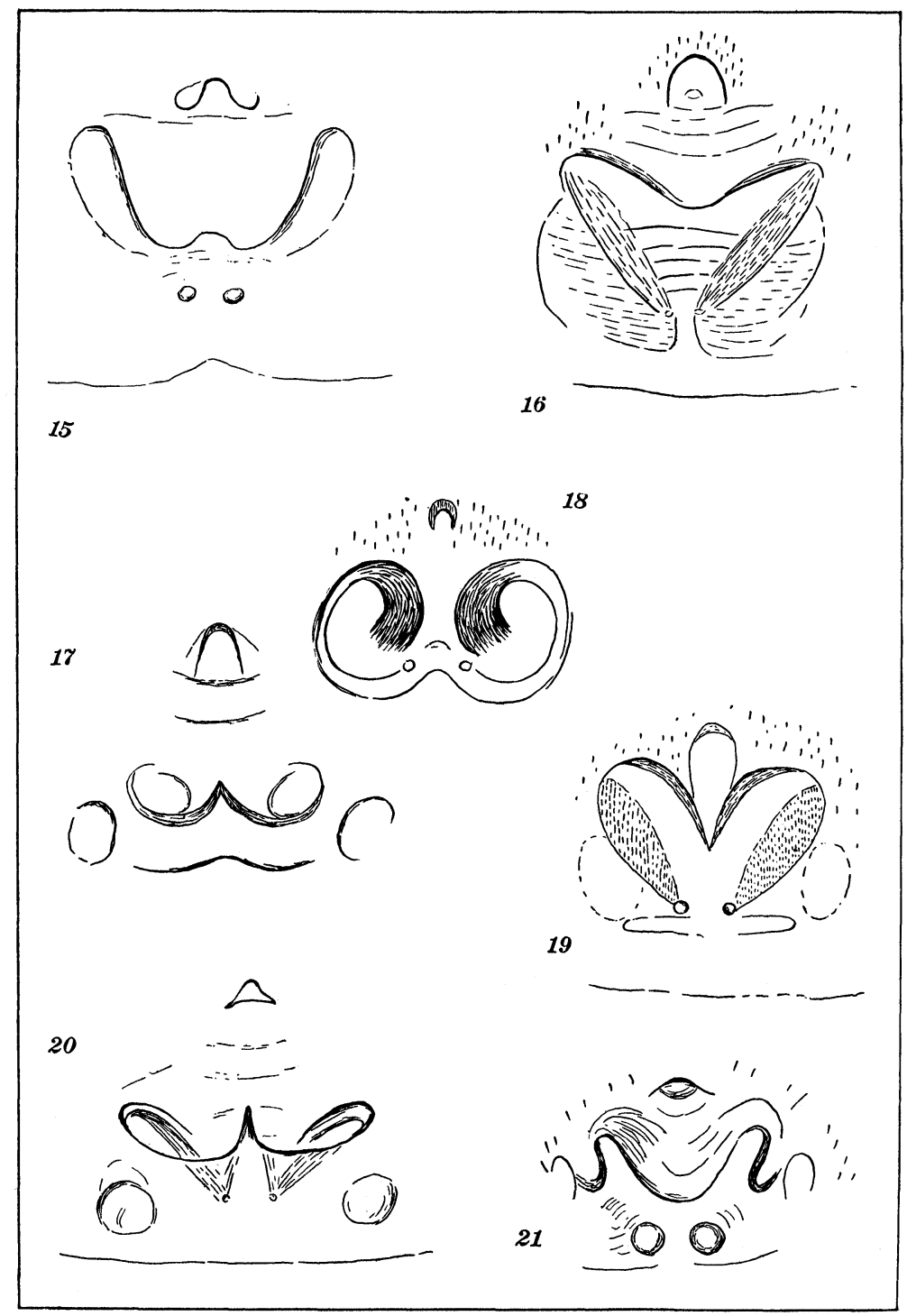

Bryant-American Ozyptila. 

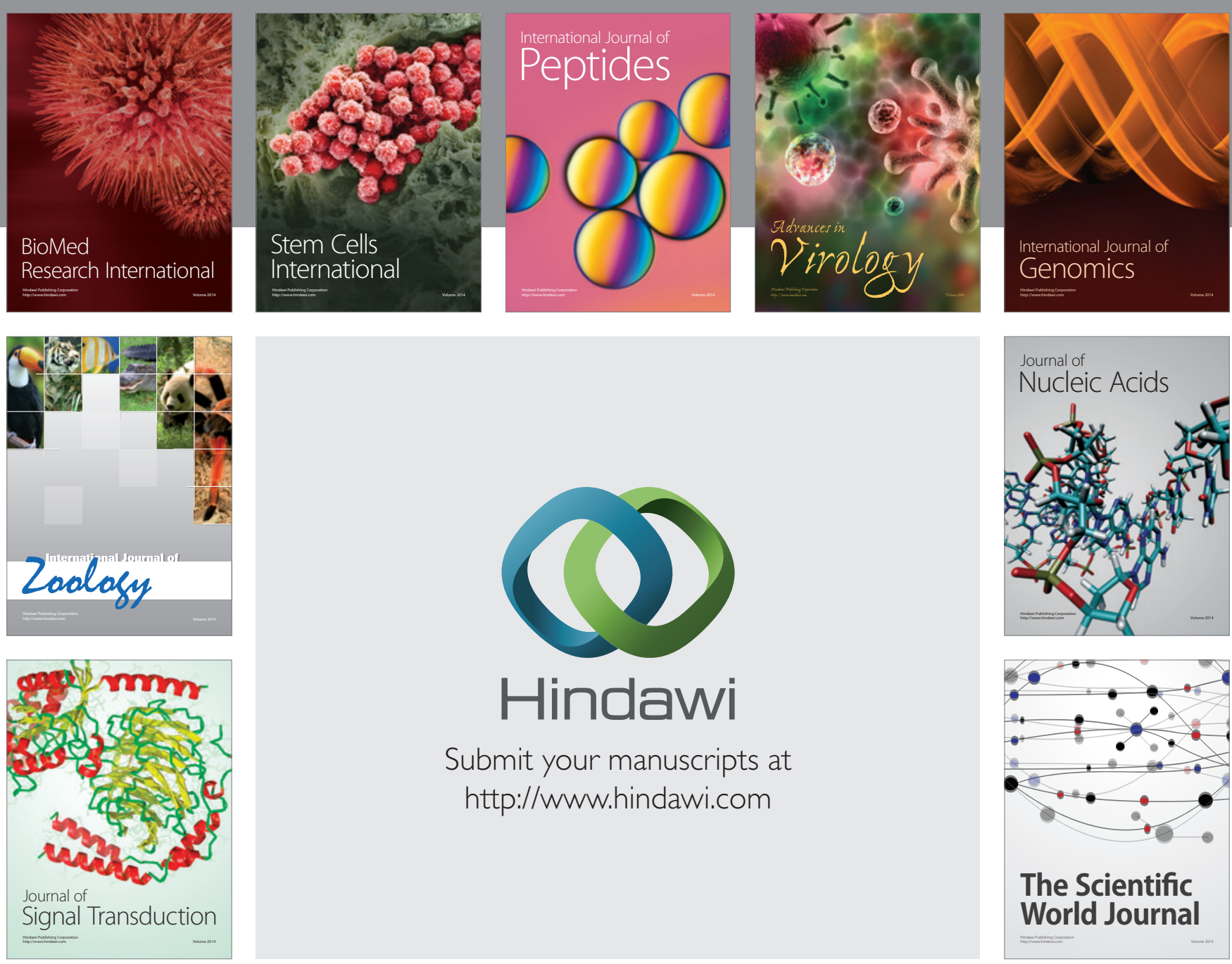

Submit your manuscripts at

http://www.hindawi.com
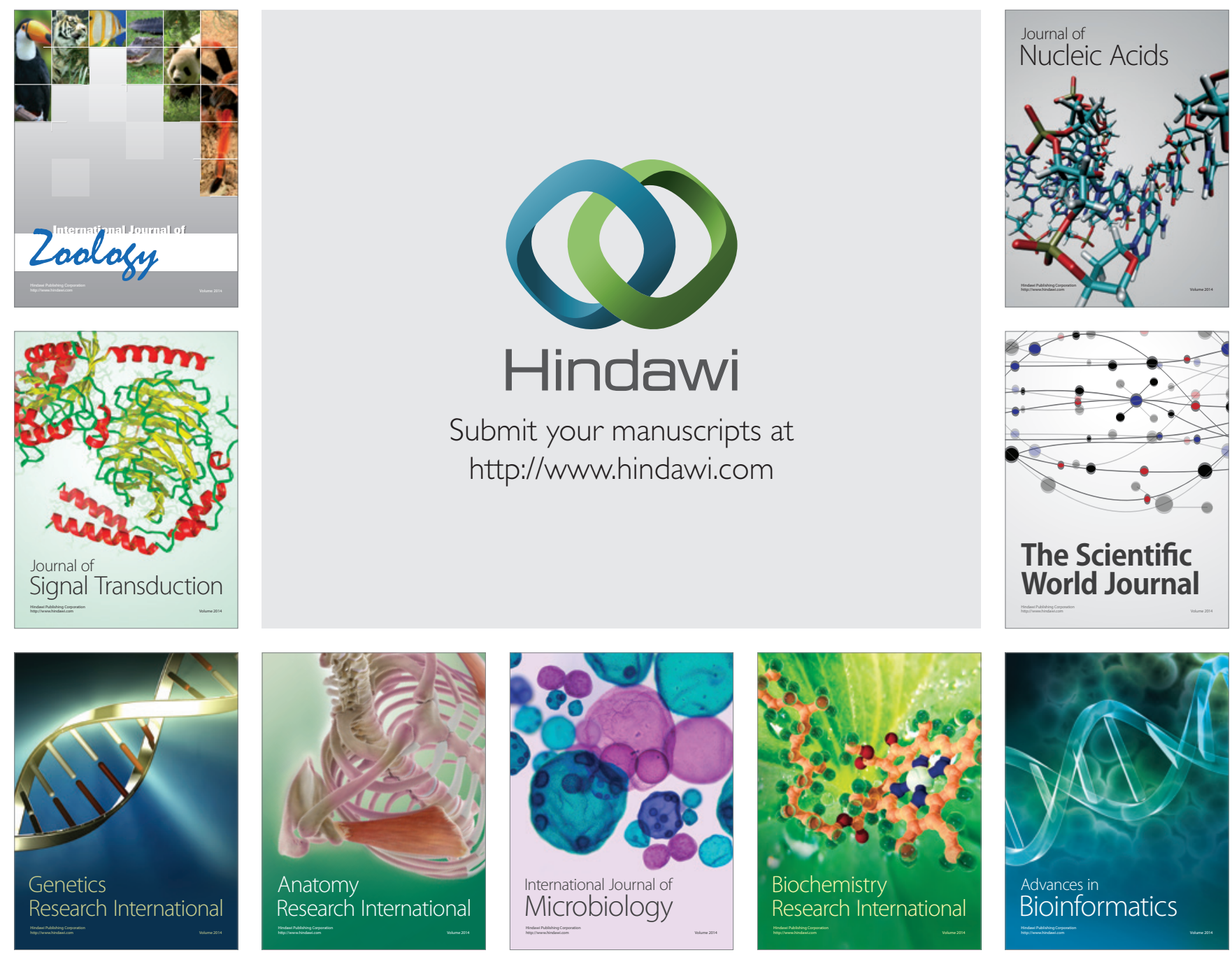

The Scientific World Journal
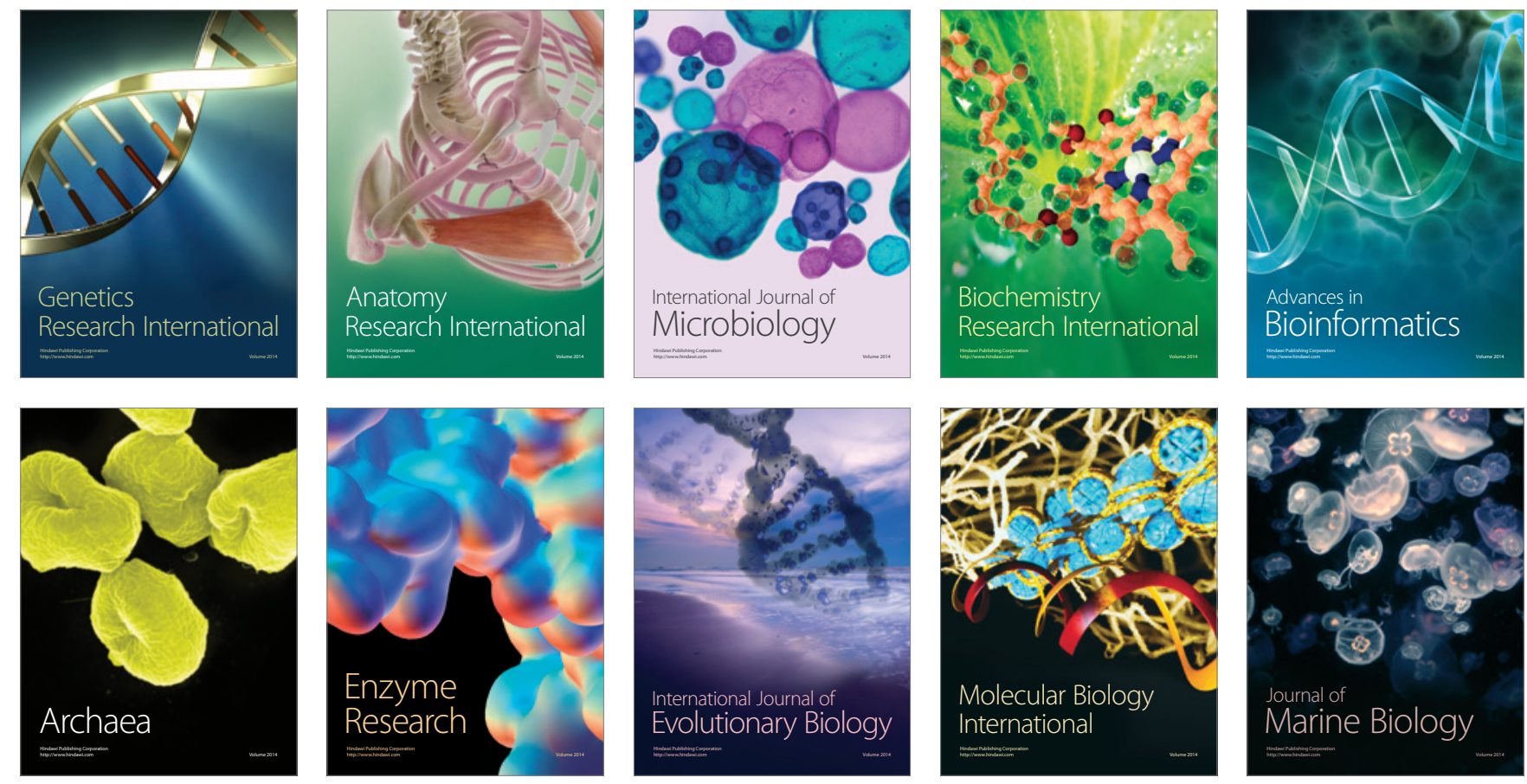